\title{
Sea-ice control on deglacial lower cell circulation changes recorded by Drake Passage deep-sea corals
}

David J. Wilson ${ }^{\mathrm{a}, \mathrm{b} *}$, Torben Struve ${ }^{\mathrm{b}, \mathrm{c}}$, Tina van de Flierdt ${ }^{\mathrm{b}}$, Tianyu Chen ${ }^{\mathrm{d}, \mathrm{e}}$, Tao Li $^{\mathrm{d}, \mathrm{e}}$, Andrea Burke ${ }^{\text {f }}$, Laura F. Robinson ${ }^{\text {d }}$

a- Institute of Earth and Planetary Sciences, University College London and Birkbeck, University of London, Gower Street, London, WC1E 6BT, UK.

b- Department of Earth Science and Engineering, Imperial College London, London, SW7 $2 A Z, U K$

c- Marine Isotope Geochemistry, Institute for Chemistry and Biology of the Marine Environment (ICBM), University of Oldenburg, Carl-von-Ossietzky-Str. 9-11, 26129

Oldenburg, Germany

d- School of Earth Sciences, University of Bristol, Wills Memorial Building, Queens Road, Bristol, BS8 1RJ, UK

e- School of Earth Sciences and Engineering, Nanjing University, Nanjing, 210023, China

f- School of Earth and Environmental Sciences, University of St Andrews, St Andrews, KY16 $9 A L, U K$

* Corresponding Author. Tel.: +44 203108 6349. Email: david.j.wilson@ucl.ac.uk

\author{
Contents: \\ abstract (292 words) \\ highlights (5) \\ key words (6) \\ main text (6594 words) \\ references $(71)$ \\ figures (5) \\ supplementary tables (1)
}

Revised manuscript for submission to Earth and Planetary Science Letters

$18^{\text {th }}$ May 2020 


\section{Highlights}

- First direct constraints on past water mass mixing in Lower Circumpolar Deep Water

- Reduced North Atlantic Deep Water signal in deep Southern Ocean during peak glacial

- Control by Southern Ocean stratification rather than Atlantic overturning strength

- Early deglacial Southern Ocean circulation changes linked to sea-ice retreat

- Spatially asynchronous return of North Atlantic Deep Water to deep South Atlantic

\section{Key words}

ocean circulation; deglaciation; Drake Passage; Nd isotopes; deep-sea corals; sea-ice

\section{Abstract}

The sequence of deep ocean circulation changes between the Last Glacial Maximum and the Holocene provides important insights for understanding deglacial climate change and the role of the deep ocean in the global carbon cycle. Although it is known that significant amounts of carbon were sequestered in a deep overturning cell during glacial periods and released during deglaciation, the driving mechanisms for these changes remain unresolved. Southern Ocean sea-ice has recently been proposed to play a critical role in setting the global deep ocean stratification and circulation, and hence carbon storage, but testing such conceptual and modelling studies requires data constraining past circulation changes. To this end, we present the first deglacial dataset of neodymium $(\mathrm{Nd})$ isotopes measured on absolute-dated deep-sea corals from modern Lower Circumpolar Deep Water depths in the Drake Passage. Our record demonstrates deglacial variability of $2.5 \varepsilon_{\mathrm{Nd}}$ units, with radiogenic values of up to $\varepsilon_{\mathrm{Nd}}=-5.9$ during the Last Glacial Maximum providing evidence for a stratified glacial circulation mode with restricted incorporation of Nd from North Atlantic Deep Water in the lower cell. During the deglaciation, a renewed Atlantic influence in the deep Southern Ocean is recorded early in Heinrich Stadial 1, coincident with Antarctic sea-ice retreat, and is followed by a brief return to more Pacific-like values during the Antarctic Cold Reversal. These changes demonstrate a strong influence of Southern Ocean processes in setting deep ocean circulation and support the proposed sea-ice control on deep ocean structure. Furthermore, by constraining the Nd isotopic composition of Lower Circumpolar Deep Water in the Southern Ocean, our new data is important for interpreting deglacial circulation changes in other ocean basins and supports a spatially asynchronous return of North Atlantic Deep Water to the deep southeast and southwest Atlantic Ocean. 


\section{Introduction}

Southern Ocean circulation dynamics play a key role in the global carbon cycle and climate system. Specifically, the combination of Southern Ocean upwelling (driven by the westerly winds) and regional buoyancy forcing sets the interior ocean structure through intermediate and deep water formation (Talley, 2013), while the Antarctic Circumpolar Current (ACC) distributes heat, salt, and carbon between the major ocean basins (Rintoul et al., 2001). As such, processes in the Southern Ocean have a global reach, and paleoceanographic reconstructions from this region provide crucial constraints on the links between ocean circulation dynamics, deep water chemistry, and climate change (e.g. Robinson and van de Flierdt, 2009; Burke and Robinson, 2012; Roberts et al., 2016; Rae et al., 2018).

In the modern ocean, there are two main overturning circulation cells: an upper cell with deep water formation in the North Atlantic (i.e., North Atlantic Deep Water, NADW) and a lower cell in which deep waters form in the Southern Ocean (i.e., Antarctic Bottom Water, AABW). These two cells are interconnected (Talley, 2013), because NADW is exported at mid-depths into the Southern Ocean, where it is incorporated into Lower Circumpolar Deep Water (LCDW) which feeds AABW formation (Fig. 1b). After ventilating the deep Indian and Pacific Oceans, those southern-sourced waters flow back into recirculating Upper Circumpolar Deep Water (UCDW), which upwells in the Southern Ocean and is exported northwards at intermediate depths, thereby resupplying the upper cell (Talley, 2013). Since the upper and lower overturning cells are connected through upwelling and mixing in the Southern Ocean, the properties of NADW and AABW are exchanged between the two cells and the modern deep ocean is relatively homogeneous.

However, this picture likely differed significantly in the past, with changes in the deep southern-sourced overturning cell being a leading candidate to explain late Pleistocene glacialinterglacial atmospheric $\mathrm{CO}_{2}$ variability (Toggweiler, 1999; Anderson et al., 2009; Sigman et al., 2010; Skinner et al., 2010; Burke and Robinson, 2012; Roberts et al., 2016; Rae et al., 2018). Physical mechanisms that could have enhanced glacial carbon sequestration in the lower cell include reduced overturning rates (Toggweiler, 1999), increased isolation from the atmosphere (Keeling and Stephens, 2001), or an increase in its volumetric contribution to the global ocean (Skinner, 2009). Recently, reduced mixing between the upper and lower cells has been proposed as the key mechanism for deep ocean carbon storage (Lund et al., 2011), leading to a renewed focus on the role of sea-ice in controlling Southern Ocean buoyancy and stratification (Ferrari et al., 2014; Nadeau et al., 2019). However, diagnosing the importance of any of these mechanisms for the carbon cycle is challenging because neither data nor models agree on the nature of the glacial lower cell circulation (e.g. Böhm et al., 2015; KurahashiNakamura et al., 2017; Du et al., 2018; Hu and Piotrowski, 2018; Muglia et al., 2018). 
A better understanding of past lower-cell dynamics requires evidence on deglacial changes within the Southern Ocean, where the challenges of strong flow speeds and poor foraminiferal preservation can be overcome using absolute-dated deep-sea corals as an archive of seawater chemistry (Robinson et al., 2014). Recent studies on fossil corals from the Drake Passage indicate that a poorly-ventilated, low-pH water mass occupied LCDW depths during the late glacial period (Burke and Robinson, 2012; Rae et al., 2018) and that its subsequent ventilation released carbon to the upper ocean and atmosphere towards the end of Heinrich Stadial 1 (Burke and Robinson, 2012; Martínez-Botí et al., 2015; Rae et al., 2018). However, a comprehensive interpretation of such changes in deep water chemistry requires independent constraints on water mass sourcing. Neodymium $(\mathrm{Nd})$ isotopes have the potential to provide insights into water mass sources to the Southern Ocean because Atlantic and Pacific-derived waters have contrasting $\mathrm{Nd}$ isotopic compositions (Carter et al., 2012; van de Flierdt et al., 2016; Struve et al., 2017) and past compositions can be reliably recovered from deep-sea corals (van de Flierdt et al., 2010; Struve et al., 2017). To date, direct evidence for deglacial Nd isotopic compositions in the Drake Passage comes from only a single coral at UCDW depths (Robinson and van de Flierdt, 2009), with no data constraining the composition of the glacial lower cell within the ACC.

To fill this important gap, we present the first late glacial and deglacial neodymium $(\mathrm{Nd})$ isotope record measured on a collection of deep-sea corals from modern LCDW depths in the Drake Passage. Our data constrain the proportions of $\mathrm{Nd}$ sourced from Atlantic versus Pacific waters in the Southern Ocean lower cell through time, and enable a multi-tracer comparison of $\mathrm{Nd}$ isotopes, radiocarbon, and boron isotopes measured on the same specimens (Burke and Robinson, 2012; Chen et al., 2015; Rae et al., 2018). Together, these data allow us to (i) address the structure of the glacial deep ocean circulation; (ii) re-assess the sequence and timing of deglacial deep ocean circulation reorganisation in the Southern Ocean; and (iii) test the proposed control of Southern Ocean sea-ice changes on global ocean circulation structure (Ferrari et al., 2014; Nadeau et al., 2019).

\section{Regional setting and samples}

The Drake Passage is the bottleneck of the circumpolar flow regime, and as such it defines the ACC (Orsi et al., 1995) and contains all major Southern Ocean water masses (Sudre et al., 2011). The mid-depths are characterised by a mixture of Atlantic-derived deep waters and recirculating Pacific waters, with a greater proportion of NADW within LCDW, and more Pacific influence (marked by lower oxygen concentrations) within UCDW (Fig. 1b) (Rintoul et al., 2001). Those water masses upwell towards the south along sloping isopycnals, and at the surface they experience either negative buoyancy forcing and flow south to become part of the lower cell (i.e., AABW), or positive buoyancy forcing and flow north to become part of the 
upper cell (i.e., Antarctic Intermediate Water, AAIW) (Rintoul et al., 2001; Ferrari et al., 2014).

114 Because LCDW upwells near Antarctica, it predominantly feeds into AABW formation, whereas UCDW feeds into the formation of AAIW and Subantarctic Mode Water (SAMW) north of the Polar Front (Fig. 1b). The deepest depths of the Drake Passage contain AABW formed in the Weddell Sea, as well as Southeast Pacific Deepwater (SPDW) formed in the high-latitude southeast Pacific Ocean (Sudre et al., 2011) (Fig. 1b).

In this study, we analysed 40 glacial and deglacial samples from 31 individual fossil coral specimens collected from three locations in the Drake Passage during expeditions NBP0805 and NBP1103 on the $R V$ Nathaniel B. Palmer (Fig. 1a). The specimens span narrow depth ranges of 1701-1750 m at Sars Seamount (north of the Polar Front; $\mathrm{n}=10$ ), 982-1196 $\mathrm{m}$ at Interim Seamount (south of the Polar Front; $\mathrm{n}=8$ ), and 806-823 $\mathrm{m}$ at Shackleton Fracture Zone (south of the Southern ACC Front; $\mathrm{n}=13$ ) (Fig. 1b). Despite their different water depths, these sample locations all currently sit within LCDW (defined by a neutral density of 28.0-28.2 $\mathrm{kgm}^{-}$ 3; Sudre et al., 2011) (Fig. 1b), or in the case of Interim Seamount straddle the boundary between LCDW and UCDW. The majority of specimens analysed were Desmophyllum dianthus $(\mathrm{n}=27)$, supplemented by data from Caryophyllia spp. $(\mathrm{n}=1)$ and Paraconotrochus antarcticus $(\mathrm{n}=3)$. In the present day, UCDW and LCDW have fairly uniform Nd isotopic compositions at the coral sampling locations $\left(\varepsilon_{\mathrm{Nd}}=-8.2 \pm 0.5,2 \mathrm{SD}\right)$ (Struve et al., 2017) that reflect the balance of Atlantic $\left(\varepsilon_{\mathrm{Nd}} \sim-13\right)$ and Pacific $\left(\varepsilon_{\mathrm{Nd}} \sim-4\right)$ waters in the Southern Ocean (van de Flierdt et al., 2016). The homogeneity of Nd isotopes in the modern Southern Ocean reflects the smaller $\mathrm{Nd}$ isotope gradient between these water masses where they enter the Southern Ocean, as well as strong diapycnal mixing within the ACC (Watson et al., 2013), although this situation may have differed in past climate states.

\section{Methods}

Most of the coral sample ages were determined by uranium-thorium dating in recent studies (Burke and Robinson, 2012; Chen et al., 2015), while additional samples were dated at the University of Bristol following the method of Chen et al. (2015) (Supplementary Table S1). Typical age uncertainties are $\sim 100-200$ years $(2 \sigma)$ for glacial and deglacial aged samples, although five samples with higher initial ${ }^{232} \mathrm{Th}$ concentrations $(>2 \mathrm{ng} / \mathrm{g}$ ) have larger age uncertainties ( $>500$ years).

Neodymium isotopes were measured on chemistry cuts of the same subsampled portions of coral that were analysed for uranium-thorium dating and therefore correspond exactly to those ages (see Struve et al., 2016 for details). Neodymium isotope analyses were conducted by thermal ionisation mass spectrometry (TIMS) or multi-collector inductively-coupled plasma mass spectrometry (MC-ICP-MS) in the MAGIC laboratories at Imperial College London. For full analytical methods, see Struve et al. (2020). Based on analyses of in-house coral and USGS 
BCR-2 rock reference materials, long term reproducibility was $\sim 0.2-0.3 \varepsilon_{\mathrm{Nd}}$ units. Data are reported for all samples in Supplementary Table S1. In presenting the data, we focus on 35 samples from 30 specimens with well-constrained ages, and do not include data from five samples with age uncertainties $>500$ years.

Considering typical deep-sea coral growth rates of $\sim 0.5-2 \mathrm{~mm} /$ year (Adkins et al., 2004), an individual measurement is expected to provide a snapshot of ocean chemistry integrated over a few decades to a century. Both $D$. dianthus and Caryophyllia spp. reliably record dissolved Nd isotopic compositions of ambient seawater in the Drake Passage (van de Flierdt et al., 2010; Struve et al., 2017), providing strong confidence in coral-based reconstructions in this setting.

\section{Results}

The Nd isotopic compositions of fossil deep-sea corals from the Drake Passage are shown by seamount and by species in Figure 2. There is good agreement between two Holocene-aged fossil corals at Sars Seamount (Struve et al., 2020) and the modern composition of CDW in the Drake Passage ( $\varepsilon_{\mathrm{Nd}}=-8.2 \pm 0.5$ ) (Fig. $2 \mathrm{a}$ ), which is consistent with the reliable recovery of past seawater $\mathrm{Nd}$ isotope signatures from coral aragonite (assuming the modern seawater composition is representative of LCDW during the Holocene). In addition, deglacial data from $P$. antarcticus (Fig. 2b), a species which is uncalibrated for $\mathrm{Nd}$ isotopes, are consistent with results from similarly-aged samples of the calibrated species D. dianthus and Caryophyllia spp. (van de Flierdt et al., 2010; Struve et al., 2017) (Fig. 2b), supporting the use of P. antarcticus for paleo-reconstructions.

The glacial and deglacial data comprise measurements from three seamounts (Fig. 2a), but we combine these datasets into a composite record representing LCDW in the Drake Passage (Fig. 2b). Combining the records is supported by (i) the similar neutral density of seawater at each of the sites in the modern ocean (Fig. 1b); (ii) the expectation that the slope of the isopycnals has not changed significantly in the past (e.g. Ferrari et al., 2014); (iii) the geographic proximity of the sites (Fig. 1a); and (iv) the consistency of the records where they overlap (Fig. 2a). While Southern Ocean frontal positions and water mass boundaries may have shifted in the past, changes in the central and southern Drake Passage region were likely minimal (McCave et al., 2013). In any case, the samples were collected from the upper levels of LCDW in the modern day (Fig. 1b), and would have remained within LCDW during any northwards frontal shifts that may have characterised the colder intervals during the past $40 \mathrm{kyr}$ (Gersonde et al., 2005).

Our combined late glacial and deglacial LCDW record shows overall variability of 2.5 $\varepsilon_{\mathrm{Nd}}$ units, ranging from values of -5.9 to -8.4 (Fig. 2b). During the glacial period (18-39 ka BP; hereafter ka), LCDW Nd isotopic compositions in the Drake Passage were between -5.9 and - 
7.7, and therefore more radiogenic than modern CDW in this region $\left(\varepsilon_{\mathrm{Nd}}=-8.2 \pm 0.5\right)$ (Struve et al., 2017). The least radiogenic glacial values $\left(\varepsilon_{\mathrm{Nd}}=-7.3\right.$ to -7.7$)$ were recorded from 26 to $39 \mathrm{ka}$, representing the latter portion of Marine Isotope Stage (MIS) 3. In contrast, the most radiogenic values $\left(\varepsilon_{\mathrm{Nd}}=-5.9\right.$ to -6.7$)$ were confined to an interval from 19 to $26 \mathrm{ka}$, approximately representing the Last Glacial Maximum (LGM), although variability in this interval was high and less radiogenic values $\left(\varepsilon_{\mathrm{Nd}}=-7.2\right.$ to -7.5$)$ were also recorded. At the end of the LGM, Nd isotopic compositions shifted at $\sim 18-20 \mathrm{ka}$ to reach values of -7.5 to -8.0 during Heinrich Stadial 1. Some rapid variability is recorded around the end of Heinrich Stadial 1 , ranging from $\varepsilon_{\mathrm{Nd}}=-6.9 \pm 0.4$ at $15.2 \mathrm{ka}$ to $\varepsilon_{\mathrm{Nd}}=-8.3 \pm 0.2$ at $14.7 \mathrm{ka}$. A return to more radiogenic values up to $\varepsilon_{\mathrm{Nd}}=-7.3 \pm 0.2$ occurred within the Bølling-Allerød/Antarctic Cold Reversal, before values became less radiogenic during the Younger Dryas and reached a modern-like composition of $\varepsilon_{\mathrm{Nd}}=-8.4 \pm 0.2$ at $11.9 \mathrm{ka}$.

\section{Discussion}

\subsection{Reduced influence of NADW in the glacial Southern Ocean lower cell}

Our coral-based $\mathrm{Nd}$ isotope data represents the first LCDW record from the Drake Passage, so it is instructive to place it in context with existing lower cell $\mathrm{Nd}$ isotope records from the wider region. Comparison to both the deep Cape Basin of the southeast Atlantic (cores RC11-83/TNO57-21; 4.7/5.0 km water depth; Piotrowski et al., 2008; Piotrowski et al., 2012) and the deep equatorial Indian Ocean (core SK129-CR2; $3.8 \mathrm{~km}$ water depth; Wilson et al., 2015) reveals very similar absolute values and temporal evolution during the glacial period and Heinrich Stadial 1 (Fig. 3c). Given the effects of bioturbation and sedimentation rates of $\sim 2$ $\mathrm{cm} / \mathrm{kyr}$ for SK129-CR2 and $\sim 15-20 \mathrm{~cm} / \mathrm{kyr}$ for RC11-83/TNO57-21, those sediment core records integrate seawater chemistry over multi-centennial to millennial timescales, whereas the coral data should be sensitive to sub-centennial variability, if present. Indeed, there does appear to be greater variability in the coral data than in those sediment core records from 18 to $22 \mathrm{ka}$, but overall the lower cell records from the Drake Passage, the Cape Basin, and the Indian Ocean are similar (Fig. 3c). We therefore infer that all three sites were ventilated by a similar water mass, presumably LCDW, throughout the glacial period and early deglaciation, and that these $\mathrm{Nd}$ isotope records represent a circumpolar signal rather than recording local circulation or input signals. Importantly, agreement between multiple locations argues against a significant control by porewater processes (Du et al., 2016) or boundary exchange (Lacan and Jeandel, 2005), consistent with modern observations from the Southern Ocean which is characterised by rapid advection (Carter et al., 2012; van de Flierdt et al., 2016). Persistent connectivity between these locations supports inter-ocean exchange of deep waters via the Southern Ocean during the glacial period (e.g. McCave et al., 2013; Lynch-Stieglitz et al., 2016). 
Given the wide geographical extent of this water mass signal, we interpret the more radiogenic $\mathrm{Nd}$ isotopic compositions of LCDW during the glacial $\left(\varepsilon_{\mathrm{Nd}}=-5.9\right.$ to -7.7$)$ compared to the Holocene and modern day $\left(\varepsilon_{\mathrm{Nd}} \sim-8.2 \pm 0.5\right.$ ) (Figs. 2b, 3c) as an increased contribution of radiogenic Nd from Pacific waters at the expense of NADW (van de Flierdt et al., 2016). This difference was most pronounced during the LGM, with four samples recording $\varepsilon_{\mathrm{Nd}}$ values of 5.9 to -6.7 (Fig. 3c), indicating a significant reduction in the proportion of NADW-derived Nd in the lower cell. This scenario could potentially arise from reduced NADW production and export (assuming relatively unchanged $\mathrm{Nd}$ isotopic compositions and concentrations in NADW), but there is strong evidence for persistent Atlantic meridional overturning circulation during the glacial period, including the LGM (McManus et al., 2004; Bradtmiller et al., 2014; Böhm et al., 2015) (Fig. 3b). We therefore rule out volumetric changes in NADW production as the controlling factor, and instead suggest that NADW incorporation into the lower cell was reduced as a result of changes in water mass geometry. A reduced influence of NADW in the global lower cell at the LGM provides strong support for a glacial circulation mode with greater stratification and more isolated upper and lower overturning cells (Ferrari et al., 2014). Enhanced glacial stratification would also be expected to maintain steeper vertical Nd isotope gradients in the Southern Ocean, such that a circulation response that is sensitive to modest sea-ice variability (WAIS Divide Project Members, 2013; Xiao et al., 2016) could potentially explain the rapid temporal variability in Nd isotopes at the LGM (Fig. 2b).

Whereas our data support the operation of a glacial circulation mode at the LGM, the Nd isotopic composition of LCDW recorded by coral samples from MIS $3\left(\varepsilon_{\mathrm{Nd}}=-7.5\right.$ to -7.7 ; Fig. $3 \mathrm{c})$ was only slightly more radiogenic than modern values $\left(\varepsilon_{\mathrm{Nd}} \sim-8.2 \pm 0.5\right)$. This observation suggests that NADW-derived Nd was still incorporated into the lower cell at times during MIS 3, consistent with the deep North Atlantic overturning inferred at these times (e.g. Bőhm et al., 2015). For stadial intervals and MIS 4, the Cape Basin record suggests that a glacial Southern Ocean circulation mode was in operation (Piotrowski et al., 2008), but as yet there are no Drake Passage coral data to constrain interpretations before $40 \mathrm{ka}$.

\subsection{Distinct local bottom water in the glacial southwest Atlantic Ocean}

In contrast to the Drake Passage, deep Cape Basin, and Indian Ocean records, a South Atlantic site on the Mid-Atlantic Ridge (core MD07-3076; 3.8 km water depth; Skinner et al., 2013 ) records distinct $\mathrm{Nd}$ isotopic compositions, which are both more radiogenic $\left(\varepsilon_{\mathrm{Nd}} \sim-5.5\right)$ and less variable during the LGM and early Heinrich Stadial 1 (Fig. 3c). Howe et al. (2016) also observed an east-west Nd isotope gradient in the deep South Atlantic at the LGM, with radiogenic compositions in the southwest Atlantic $\left(\varepsilon_{\mathrm{Nd}} \sim-5\right.$ in core RC15-94 at $3.8 \mathrm{~km}$ and core $\mathrm{RC} 12-267$ at $4.1 \mathrm{~km})$ but not in the southeast Atlantic $\left(\varepsilon_{\mathrm{Nd}}=-6.4\right.$ in core TN057-6 PC4 at 3.7 
along the same flow path as those other sites, and was influenced by a different bottom water source with a radiogenic $\mathrm{Nd}$ isotopic composition.

During the LGM, AABW formation in the Weddell Sea was probably restricted by the expansion of grounded ice (Hillenbrand et al., 2014; Huang et al., 2020), although a glacial version of AABW could potentially have formed in open-ocean polynyas (Cheon and Gordon, 2019) or coastal polynyas along the West Antarctic Peninsula (Smith et al., 2010). In the latter case, interaction with the volcanogenic lithologies of that region (Struve et al., 2017) could have produced a variety of $\mathrm{AABW}$ with a more radiogenic $\mathrm{Nd}$ isotopic composition than its modern counterpart ( $\varepsilon_{\mathrm{Nd}} \sim-9$; van de Flierdt et al., 2016). Assuming a flow path into the southwest Atlantic Ocean similar to modern AABW (Rintoul et al., 2001), such a water mass could have affected site MD07-3076 on the Mid-Atlantic Ridge without influencing the Drake Passage. For this mechanism to be correct, ice in the Weddell Sea must have remained grounded until at least $\sim 17.5 \mathrm{ka}$ (Fig. 3c). However, evidence for the timing of ice retreat in the Weddell Sea is inconclusive (Hillenbrand et al., 2014), with estimates ranging from $\sim 19$ to 20 ka (Smith et al., 2010) to 14 to 15 ka (Weber et al., 2011; Golledge et al., 2014).

An alternative possibility is that the deep southwest Atlantic was influenced by a bottom water mass that formed in the South Pacific sector of the Southern Ocean and traversed the Drake Passage below the LCDW depths monitored by our corals. In the modern ocean, SPDW follows such a pathway (Sudre et al., 2011) (Fig. 1b). However, while SPDW has a relatively radiogenic $\mathrm{Nd}$ isotopic composition $\left(\varepsilon_{\mathrm{Nd}} \sim-7\right)$ near its source region (Carter et al., 2012), it is not isotopically distinct from LCDW in the Drake Passage (Struve et al., 2017). For a glacial analogue of SPDW to have controlled the MD07-3076 record requires both a more radiogenic $\mathrm{Nd}$ isotopic composition for SPDW at the LGM and more efficient transport of this signal into the South Atlantic. A more radiogenic composition for SPDW seems feasible given the radiogenic Nd isotopic compositions on the modern Amundsen Sea shelves (Carter et al., 2012) and the greater isolation between Atlantic and Pacific overturning cells proposed for the LGM (Ferrari et al., 2014; Sikes et al., 2017). It is also supported by the Nd isotopic compositions of around -6 recorded during the glacial period in southeast Pacific cores E11-2 $(3.1 \mathrm{~km})$ and PS75/056 (3.6 km) (Basak et al., 2018).

The uniquely radiogenic $\mathrm{Nd}$ isotopic composition of the glacial deep water mass at MD07-3076 in comparison to other LCDW records (Fig. 3c) is also matched by larger radiocarbon age offsets from the atmosphere (B-Atm 2700-3700 years; Skinner et al., 2013) in comparison to LCDW in the Drake Passage (B-Atm 1700-2400 years; Burke and Robinson, 2012) and deep Cape Basin (B-Atm 1200-2000 years; Barker et al., 2010). These extreme properties emphasise its distinct sourcing and could point towards radiocarbon-depleted Pacific waters (Skinner et al., 2017) in its source region. We therefore favour a localised origin in the southeast Pacific sector of the Southern Ocean, but future studies from this region will be required to test this idea. 


\subsection{Early deglacial Southern Ocean circulation changes linked to sea-ice retreat}

305

306

307

308

309

310

311

312

313

314

315

316

317

318

319

320

321

322

323

324

325

326

327

328

329

330

331

332

333

334

335

336

337

338

339

340

A striking feature of our new LCDW record is the change at $\sim 18-20 \mathrm{ka}$ from highly radiogenic $\mathrm{Nd}$ isotopic compositions that characterise much of the LGM (-6 to -6.5$)$ towards consistently less radiogenic compositions during Heinrich Stadial 1 (-7.5 to -8) (Fig. 3c), implying an increase in the proportion of Nd derived from NADW in the deep Southern Ocean. A deglacial shift towards unradiogenic values is also seen in other South Atlantic and Indian Ocean records (e.g. Piotrowski et al., 2008; Skinner et al., 2013; Wilson et al., 2015), and has often been interpreted in terms of strengthened NADW formation and its downstream advection. However, the Drake Passage changes occurred early in the deglaciation, coinciding with a weakening of Atlantic overturning circulation during Heinrich Stadial 1 (McManus et al., 2004; Bradtmiller et al., 2014; Bőhm et al., 2015) (Fig. 3b). Since the corals have absolute ages with uncertainties of only a few hundred years, it is a robust observation that the early deglacial shift in the Drake Passage precedes the strengthening and deepening of Atlantic overturning at the onset of the Bølling-Allerod (McManus et al., 2004; Barker et al., 2010). The Drake Passage changes also precede deglacial Nd isotope changes in the North Atlantic region (Böhm et al., 2015; Zhao et al., 2019) so cannot be attributed to changes in the $\mathrm{Nd}$ isotopic composition of NADW, while the Pacific Nd isotopic composition appears to have been approximately constant between the LGM and Holocene (Hu et al., 2016). Therefore, it appears that Southern Ocean processes may have increased the incorporation of unradiogenic Nd from NADW into the lower cell at this time, despite reduced NADW production.

In Figure 4, we compare the Drake Passage Nd isotope record to ice-core reconstructions of regional temperature and sea-ice extent. The WAIS Divide Core records both an early interval of deglacial warming from $\sim 18$ to $22 \mathrm{ka}$ (arrow on Fig. 4f), linked to regional insolation forcing (WAIS Divide Project Members, 2013), as well as a major warming event within Heinrich Stadial 1 (orange bar on Fig. 4). The early warming coincided with a rapid decrease in sea-salt sodium concentrations at $\sim 19-20 \mathrm{ka}$ (Fig. 4d), interpreted to record winter sea-ice retreat and reduction of the sea-ice zone (WAIS Divide Project Members, 2013), with a second rapid decrease at around $\sim 17.5 \mathrm{ka}$ within early Heinrich Stadial 1. Therefore, the radiogenic $\mathrm{Nd}$ isotopic compositions of LCDW during the LGM occurred within an interval of extended sea-ice, while the shift towards unradiogenic compositions at $\sim 18-20$ ka coincided with local warming and reduced sea-ice extent (Fig. 4). Reconstructions of sea-ice extent based on diatom abundance in sediment cores also indicate early deglacial warming and sea-ice retreat at $\sim 19$ ka in the southwest Atlantic (Allen et al., 2005; Xiao et al., 2016), southeast Atlantic (Shemesh et al., 2002), and Indo-Pacific sectors (Crosta et al., 2004).

Taken together, both the ice core and marine records indicate a link between increased glacial sea-ice extent and reduced NADW incorporation into the lower cell, which supports 
hypotheses of a sea-ice control on ocean structure (Ferrari et al., 2014; Nadeau et al., 2019). According to Ferrari et al. (2014), the position of the summer sea-ice edge approximates the boundary between positive and negative buoyancy forcing, such that extended sea-ice would shoal the boundary between the upper and lower cells and reduce diapycnal mixing by rough seafloor bathymetry, ultimately decreasing NADW incorporation into the lower cell. Alternatively, Nadeau et al. (2019) emphasise that increased sea-ice production rates (independent of latitudinal extent) would increase the density of the lower cell, thereby stratifying the deep ocean and shoaling the northern-sourced branch of the upper cell. Our evidence for a link between deglacial sea-ice retreat and deep ocean circulation changes (Fig. 4 ) is consistent with the operation of either, or both, of these mechanisms. It is challenging to distinguish between the mechanisms because of the difficulty constraining both summer and winter sea-ice extent and sea-ice production in the past. However, one possibility is that deep ocean circulation changes occurred early in the deglacial sequence, responding sensitively to sea-ice changes forced by regional insolation (Fig. 4c,d), whereas increased surface upwelling and $\mathrm{CO}_{2}$ outgassing during Heinrich Stadial 1 (Anderson et al., 2009; Martínez-Botí et al., 2015) may have required more extensive summer sea-ice retreat (Fig. 4d,e).

During late Heinrich Stadial 1, the Nd isotopic composition of LCDW in both the Drake Passage and the Cape Basin was around -7.5 to -8 (Fig. 3c), suggesting that the Southern Ocean 
circulation was approaching the modern regime. The southern-sourced deep waters at MidAtlantic Ridge site MD07-3076 also became less radiogenic, leading to a diminished gradient between MD07-3076 and the LCDW corals by the end of Heinrich Stadial 1 (Fig. 3c). The emergence of more homogeneous $\mathrm{Nd}$ isotope signatures in the deep Southern Ocean around the Heinrich Stadial 1 to Bølling-Allerød transition is consistent with the timing of Southern Ocean de-stratification inferred from radiocarbon (Burke and Robinson, 2012).

However, this transition towards a modern-like state was interrupted by a shift back towards a more radiogenic $\mathrm{Nd}$ isotopic composition for LCDW of $-7.3 \pm 0.2$ at $14.1 \mathrm{ka}$, closely following the trend of the Antarctic Cold Reversal (Fig. 3c,d). More radiogenic values at this time seem surprising, given that NADW production during the Bølling-Allerød was strong and deep (McManus et al., 2004; Piotrowski et al., 2008; Barker et al., 2010) (Fig. 3b). However, Southern Ocean cooling and sea-ice expansion during the Antarctic Cold Reversal (Fig. 4d,f) could have shoaled the boundary between the upper and lower cells, once again reducing the incorporation of NADW into the lower cell. Unlike the LGM, the changes during the Antarctic Cold Reversal were short-lived and less extreme, with the Nd isotopic composition of LCDW returning to unradiogenic values by the Younger Dryas $\left(\varepsilon_{\mathrm{Nd}} \sim-7.8\right.$ to -8.4$)$ (Fig. 3c), indicating renewed mixing and establishment of a modern-like circulation mode at this time.

In the South Pacific, Basak et al. (2018) proposed that the deglacial transition towards a modern-like Southern Ocean circulation structure had two steps, during Heinrich Stadial 1 and the Younger Dryas, while benthic carbon isotope records from near New Zealand indicate more gradual changes starting before Heinrich Stadial 1 and continuing until the early Holocene (Clementi et al., 2019). Our observations of early deglacial changes, a transient shift towards a modern-like ocean structure by the end of Heinrich Stadial 1, and a permanent recovery towards modern $\mathrm{Nd}$ isotopic compositions after the Antarctic Cold Reversal, are broadly consistent with these studies. In particular, the link with Antarctic climate evolution emphasises the importance of Southern Ocean processes (Fig. 4) over NADW production (Fig. 3b) for setting the chemistry of the global lower cell. However, future research will be required to explore whether the more abrupt deglacial changes in the Drake Passage versus more protracted changes in the Pacific Ocean reflect a difference of resolution between sediment core and coral records, or regional differences between these settings.

\subsection{Establishment of the Holocene Atlantic circulation mode}

We demonstrated above that the deep Cape Basin was ventilated by LCDW during the glacial period and Heinrich Stadial 1, with its Nd isotopic composition tracking LCDW in the Drake Passage (Section 5.1). In contrast, during the Holocene, the deep Cape Basin is offset by 1-2 $\varepsilon_{\mathrm{Nd}}$ units towards a less radiogenic Nd isotopic composition than LCDW (Fig. 3c), which reflects a contribution of NADW to that basin. Comparing those two records reveals that this 
modern gradient first emerged during the Bølling-Allerød/Antarctic Cold Reversal, when the deep Cape Basin became increasingly unradiogenic while LCDW in the Drake Passage returned to more radiogenic values (Fig. 3c). We attribute this change to a southward extension and/or deepening of the unradiogenic tongue of NADW, forming a mixing zone between NADW and LCDW in the deep Cape Basin. By constraining the composition of LCDW, our data supports the emergence of a modern-like Atlantic circulation in this region at the BøllingAllerød transition, strengthening previous inferences from individual proxy records (Piotrowski et al., 2008; Barker et al., 2010).

In contrast, comparing the Nd isotope record from Mid-Atlantic Ridge site MD07-3076 (Skinner et al., 2013) to the Drake Passage coral record suggests a later onset for a modern-like circulation pattern in the southwest Atlantic Ocean. During the LGM and Heinrich Stadial 1, MD07-3076 was ventilated by a distinct water mass with a more radiogenic $\mathrm{Nd}$ isotopic composition than LCDW (Section 5.2), whereas its composition during the Bølling-Allerød and Younger Dryas matched the Drake Passage corals (Fig. 3c). Therefore, while a change of water mass origin at MD07-3076 did occur at the onset of the Bølling-Allerød, we infer that it was still ventilated by southern-sourced waters, which supports the interpretation of improved ventilation of southern-sourced waters during Heinrich Stadial 1 and the Bølling-Allerød (Skinner et al., 2013). The MD07-3076 record only diverges from the Drake Passage record during the early Holocene, indicating the arrival of unradiogenic NADW in the southwest Atlantic at this time (Fig. 3c).

The earlier deglacial return of NADW to the deep Cape Basin (Bølling-Allerød) than to the Mid-Atlantic Ridge (early Holocene) (Fig. 3c) appears to reflect their positions with respect to the flow paths of NADW and AABW. In the modern ocean, the main export pathway for NADW is via the southeast Atlantic, whereas AABW inflow is more important in the southwest Atlantic where it flows northwards in a deep western boundary current (Rintoul et al., 2001). Therefore, the later return of NADW to site MD07-3076 could indicate a delay in establishing a full-strength Holocene Atlantic circulation mode, with NADW reaching the deep Cape Basin but not MD07-3076 during the Bølling-Allerød, consistent with model results (Barker et al., 2010). The dynamics of southern-sourced water formation may also have contributed to this spatial asynchrony, with extremely dense waters at MD07-3076 during both the glacial period and deglaciation (Roberts et al., 2016) restricting the penetration of NADW into the deep western basin. In support of that idea, the early Holocene return of NADW to MD07-3076 inferred from $\mathrm{Nd}$ isotope gradients (Fig. 3c) coincides with a switch to less dense waters at MD07-3076 (Roberts et al., 2016).

\subsection{Relationship between lower cell circulation, chemistry, and carbon storage}



changes, using a multi-proxy comparison of $\mathrm{Nd}$ isotopes, radiocarbon, and boron isotopes. All three tracers record significant glacial-interglacial changes in LCDW, with the most extreme values during the LGM (Fig. 4a-c). Ventilation ages (B-Atm) during the LGM were 1700 2400 years (Burke and Robinson, 2012; Chen et al., 2015), up to double those in modern LCDW, and boron isotope values indicate low-pH conditions (Rae et al., 2018). Hence, to first order, a reduced NADW contribution to the lower cell was linked to greater isolation from the atmosphere and enhanced carbon storage. Given the low atmospheric $\mathrm{CO}_{2}$ concentrations during the LGM ( 185-195 ppm; Fig. 4e), our Nd isotope data are consistent with a role for ocean circulation changes in carbon drawdown, in particular supporting hypotheses that seaice expansion enhanced deep ocean stratification and restricted connectivity between upper and lower cells (Ferrari et al., 2014; Nadeau et al., 2019; Stein et al., 2020). A reduced proportion of Atlantic-sourced waters in LCDW at the LGM is also consistent with a ventilation volume hypothesis (Skinner, 2009). During MIS 3, atmospheric $\mathrm{CO}_{2}$ concentrations were also low ( 200-215 ppm; Fig. 4e) whereas water mass sourcing in LCDW appears to have been quite similar to modern (Fig. 4c), which supports a maximum direct contribution of water mass source changes to $\mathrm{CO}_{2}$ drawdown of a few tens of ppm (Hain et al., 2010). Our inference of similar water mass sourcing between MIS 3 and the Holocene, together with the coupled variability in $\mathrm{Nd}$ isotopes and radiocarbon during the LGM (Fig. 5), also suggests that ocean circulation and stratification may be more sensitive to glacial sea-ice dynamics than indicated in current models (Stein et al., 2020).

Interestingly, when considering the transitions into and out of the LGM in detail, the covariation among these tracers breaks down. The excursion to poorly-ventilated, low-pH waters at $\sim 27 \mathrm{ka}$ preceded the reduction in the NADW contribution inferred from $\mathrm{Nd}$ isotopes (Fig. $4 \mathrm{a}-\mathrm{c}$ ), while the $\mathrm{pH}$ and ventilation did not change significantly with the increased contribution of Atlantic-sourced waters at $\sim 18-20 \mathrm{ka}$. Decoupling between these tracers is a robust observation because measurements were made on the same specimens, which only allows offsets of up to $\sim 100$ years. This relationship is highlighted in a cross-plot of ventilation ages against $\mathrm{Nd}$ isotopes (Fig. 5a), with covariation along gentle slopes indicating water mass mixing, in contrast to steep jumps between 35 and $27 \mathrm{ka}$ and at $\sim 15.4 \mathrm{ka}$ which indicate major changes in ventilation. While it is challenging to separate changes in deep ocean residence times from changes in ocean-atmosphere exchange in deep water formation regions, it is clear that LGM radiocarbon ages in LCDW were at least $\sim 600$ years older than would be predicted from the modern water mass mixing relationship (Fig. 5). This finding is important because it indicates that large changes in carbon storage (inferred from radiocarbon and boron isotopes) can occur independent of water mass sourcing, supporting a process control on carbon storage 

how such transient events may have operated. Notably, reduced ventilation and a decrease in $\mathrm{pH}$ is recorded in a coral with unradiogenic $\mathrm{Nd}$ isotopes at $27.2 \mathrm{ka}$ (Figs. 4, 5), which points to the incorporation or 'trapping' of NADW within the lower cell during initial sea-ice advance,

495

496

497

498

499

500

501

502

503

504

505

506

507

508

509

510

511

512

513

514

515

516

517

518

519

520

521

522

523

524

525

526

527

528 as predicted by Ferrari et al. (2014). The incorporation of northern-ventilated waters with low preformed nutrient contents into the southern-sourced lower cell would also have enhanced the $\mathrm{CO}_{2}$ drawdown capacity (Hain et al., 2010). As the lower cell became isolated from Atlantic waters, it would be expected to have acquired $\mathrm{Nd}$ isotope properties reflecting radiogenic $\mathrm{Nd}$ sources in the deep Pacific Ocean (Hu et al., 2016; Du et al., 2018), which is indeed seen in the radiogenic $\mathrm{Nd}$ isotopic compositions of subsequent LGM corals (Fig. 4c) and in coupled trends towards older radiocarbon ages (Fig. 5a).

At the end of the LGM, the Nd isotope shift in LCDW corals at $\sim 18-20$ ka preceded the major step in both ventilation and $\mathrm{pH}$ near the end of Heinrich Stadial 1 (Figs. 4, 5). While the replacement of Indo-Pacific deep waters with Atlantic waters by early Heinrich Stadial 1 appears to reflect a high sensitivity of deep ocean circulation to sea-ice changes (Fig. 4c,d), this change preceded the deglacial $\mathrm{CO}_{2}$ rise (Fig. 4e). The coincidence of poor ventilation and low-pH conditions with unradiogenic $\mathrm{Nd}$ isotopes could indicate that the Atlantic waters influencing the lower cell during early Heinrich Stadial 1 were themselves aged and carbonrich, consistent with glacial carbon storage in the Atlantic Ocean (e.g. Yu et al., 2016; Skinner et al., 2017). However, in this case, the evasion of $\mathrm{CO}_{2}$ that might be expected to have coincided with a reduction in deep stratification must have been hindered by a remaining summer sea-ice barrier (Keeling and Stephens, 2001) and/or misaligned Southern Hemisphere westerly winds that limited near-surface upwelling (Anderson et al., 2009). Such temporal decoupling hints at differing roles for sea-ice and westerly winds in the deglacial climate sequence. Whereas the upper cell circulation in the Drake Passage appears to be sensitive to westerly wind forcing during the Holocene (Struve et al., 2020), the limited evidence from LCDW depths provides no indication of wind-driven Holocene variability in the lower cell (Fig. 2b). However, future studies should explore the potential for coupled interactions between the sea-ice, ocean circulation, and westerly winds during the last glacial cycle.

\section{Conclusions}

This study provides the first direct constraints from the Drake Passage on glacial and deglacial water mass sourcing in LCDW, with implications for ocean circulation dynamics and carbon storage on glacial-interglacial and millennial timescales. Using $\mathrm{Nd}$ isotopes to trace the balance of unradiogenic Atlantic and radiogenic Pacific waters, we demonstrate a significant reduction in the contribution of NADW to the lower cell during the LGM, and an early deglacial shift towards an increased Atlantic component during Heinrich Stadial 1. These 
529 changes were closely linked to Southern Ocean climate and sea-ice controls, supporting an 530 emerging hypothesis that increased sea-ice extent and/or sea-ice production can shoal the 531 boundary between upper and lower overturning cells and stratify the deep ocean (Ferrari et al., 532 2014; Nadeau et al., 2019). We infer ongoing incorporation of NADW into the lower cell 533 during Heinrich Stadial 1 and the Younger Dryas, but reduced NADW proportions during the 534 Bølling-Allerød/Antarctic Cold Reversal, which provides a clear demonstration that Southern 535 Ocean structure (rather than Atlantic overturning strength) is the dominant control on water 536 mass sourcing in the deep Southern Ocean. Finally, we emphasise that our evidence on LCDW 537 composition in the Drake Passage provides new constraints on water mass sourcing in other 538 ocean basins and indicates a spatially asynchronous deglacial return of NADW to the deep 539 south Atlantic Ocean.

540

541 Acknowledgments

542

543 We acknowledge the science teams and crews of expeditions NBP0805 and NBP1103 for 544 collecting the sample material, and K. Kreissig and B. Coles for maintaining the laboratory 545 facilities in the MAGIC group. We also thank two anonymous reviewers for their positive and 546 helpful comments. Financial support to DJW, TS, and TvdF was provided by the National 547 Environmental Research Council (NE/N001141/1), the Leverhulme Trust (RPG-398), the 548 Grantham Institute for Climate Change and the Environment, and a Marie Curie Reintegration 549 grant (IRG 230828). LFR acknowledges support from the Natural Environment Research 550 Council (NE/N003861/1) and the European Research Council. 

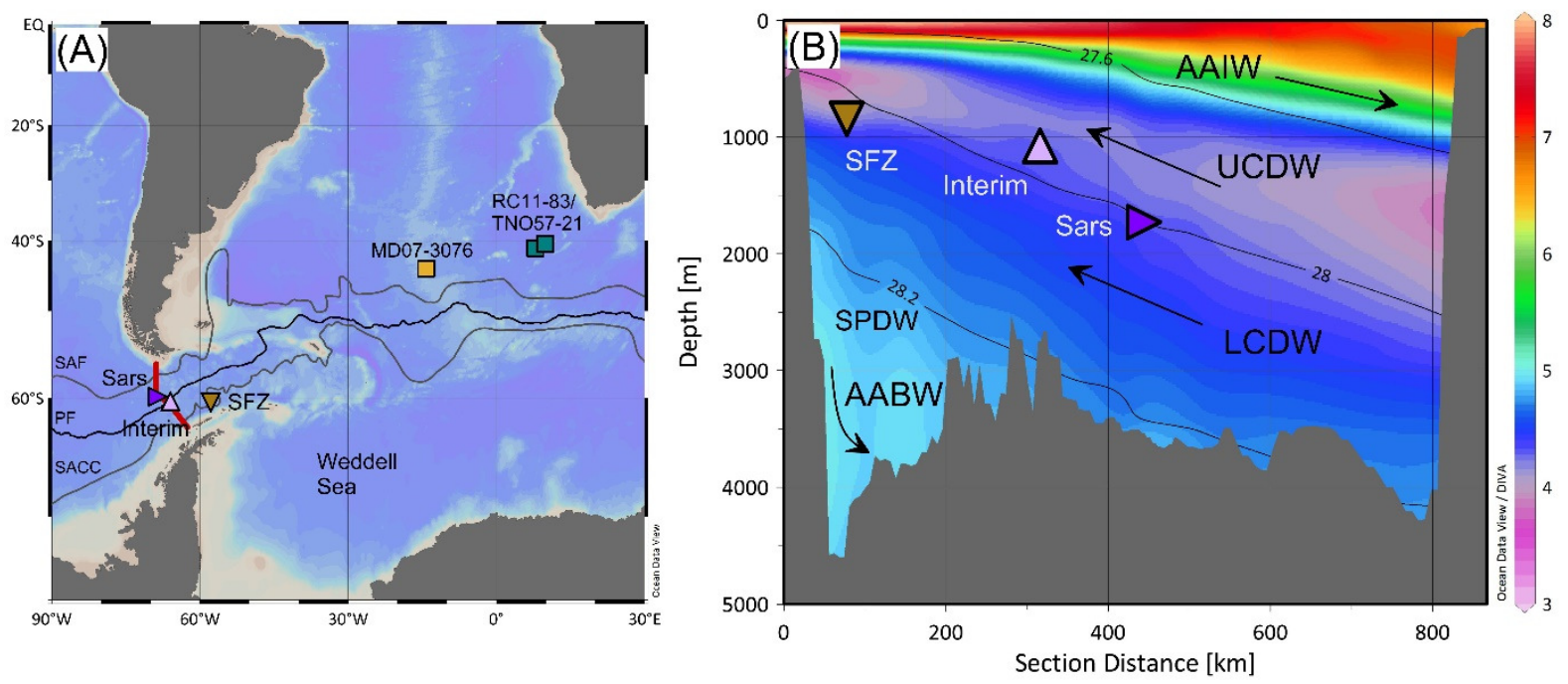

Fig. 1: Location map and hydrographic section across the Drake Passage. (a) Location of the Drake

Passage coral samples and South Atlantic sediment cores from the Cape Basin (RC11-83/TNO57-21; Piotrowski et al., 2008; Piotrowski et al., 2012) and Mid-Atlantic Ridge (MD07-3076; Skinner et al., 2013). Also shown are mean positions of the surface fronts of the ACC (Orsi et al., 1995): SAF, Subantarctic Front; PF, Polar Front; SACC, Southern ACC Front. SFZ, Shackleton Fracture Zone. (b) Section across the Drake Passage showing oxygen in $\mathrm{ml} / \mathrm{l}$ (coloured; Garcia et al., 2014), neutral density anomaly in $\mathrm{kgm}^{-3}$ (black contour lines; Jackett and McDougall, 1997), and sub-surface water masses (Rintoul et al., 2001; Sudre et al., 2011). AAIW, Antarctic Intermediate Water; UCDW, Upper Circumpolar Deep Water; LCDW, Lower Circumpolar Deep Water; SPDW, Southeast Pacific Deep Water; AABW, Antarctic Bottom Water. 


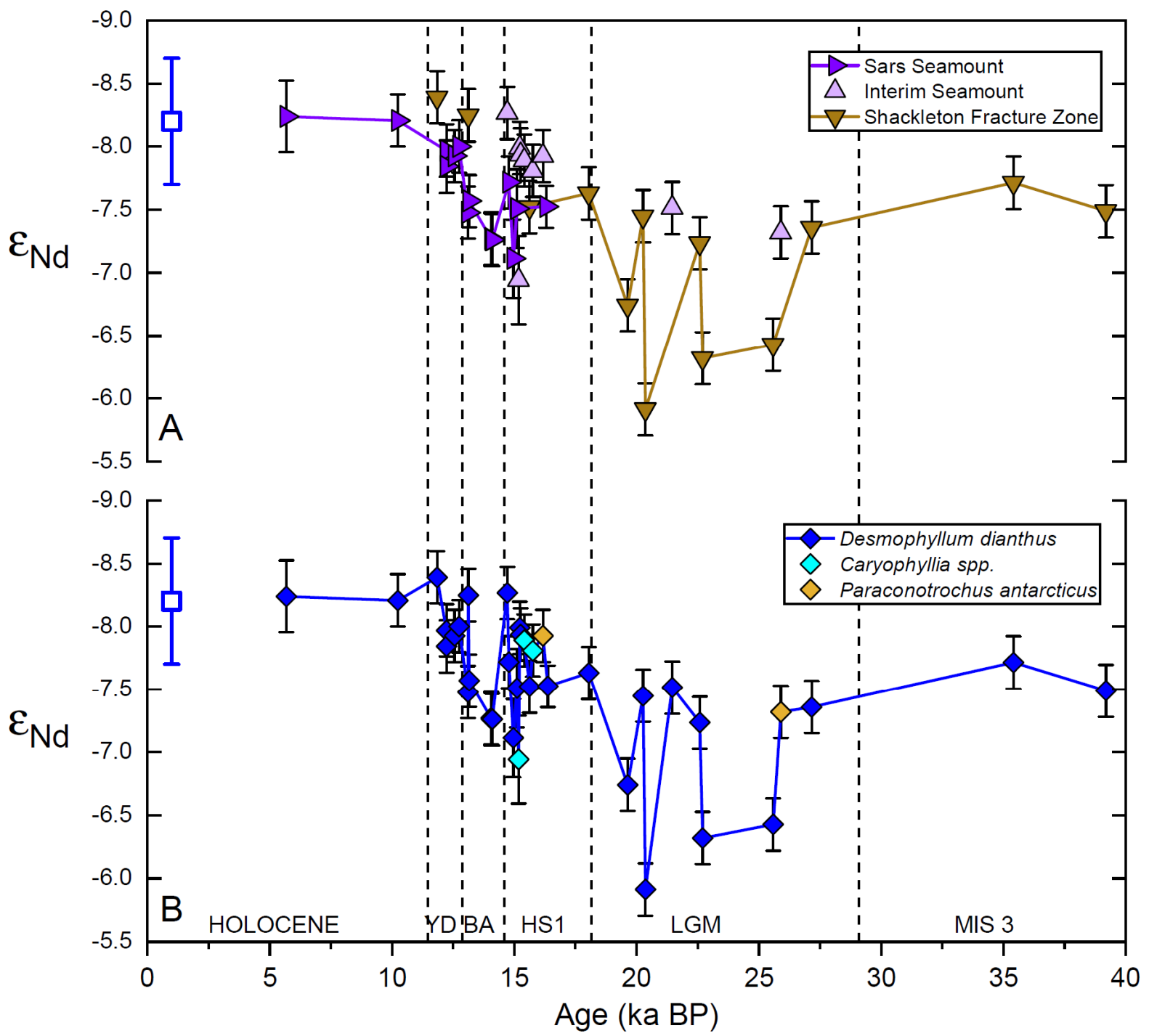

Fig. 2: Drake Passage coral Nd isotope data from 0 to $40 \mathrm{ka}$. (a) Data by seamount plotted as symbols, with lines connecting the Sars Seamount data from 5.8 to 16.4 ka and the Shackleton Fracture Zone data from 15.6 to $39.2 \mathrm{ka}$. (b) Composite record of all coral data representing LCDW, with species distinguished by coloured symbols. The modern range of seawater compositions for CDW in the Drake Passage (mean and 2SD, n=15) is shown on both panels near the y-axis (open blue square; Struve et al., 2017). Uncertainties for Nd isotopes are $2 \sigma$. Uncertainties on ages are comparable to or smaller than the symbol size. YD, Younger Dryas; BA, Bølling-Allerød; HS1, Heinrich Stadial 1; LGM, Last Glacial 


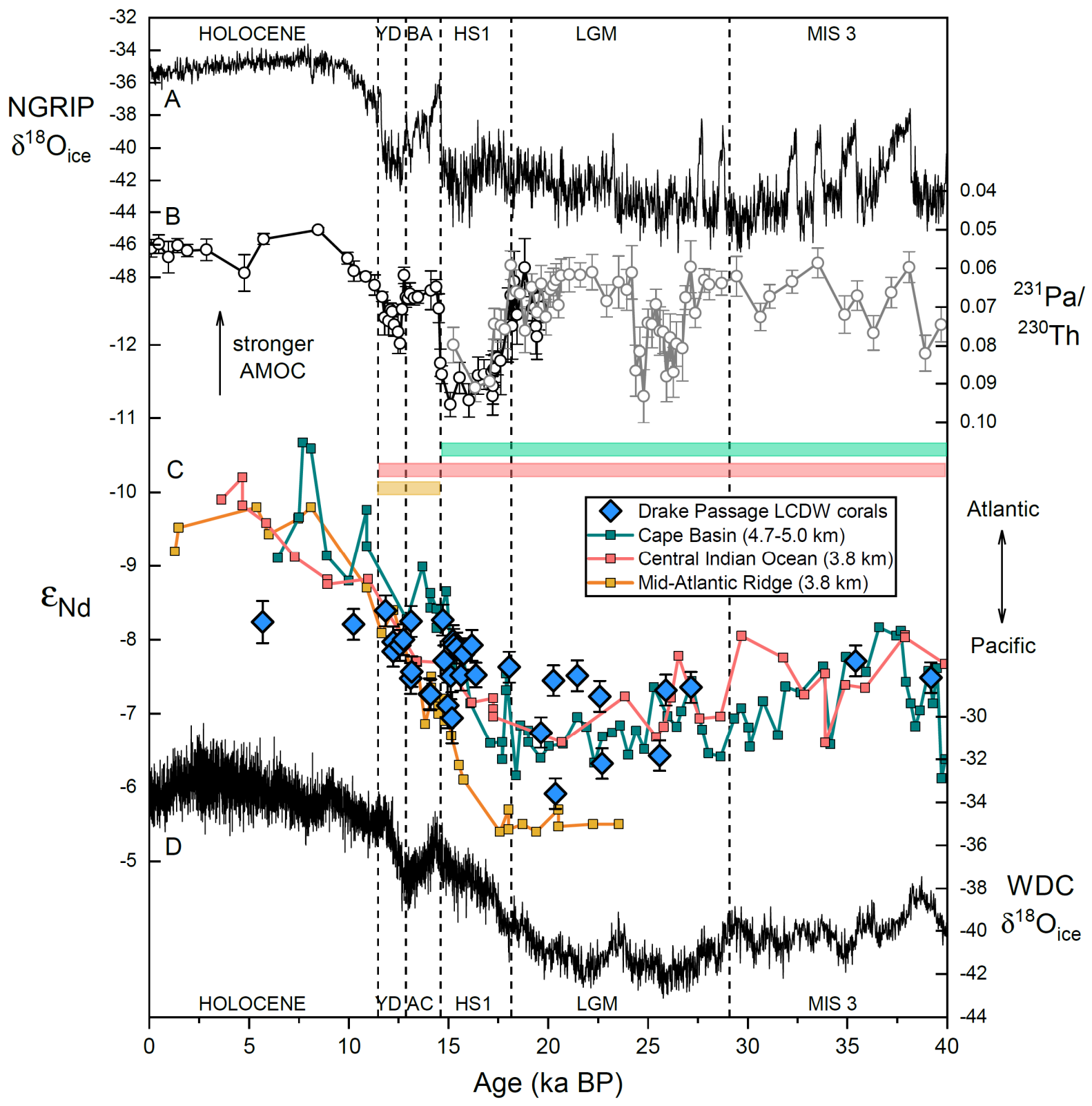

Fig. 3: Comparison of Drake Passage coral Nd isotopes to other lower cell Nd isotope records and Atlantic overturning reconstructions in a global climate context. (a) Greenland temperature proxy $\delta^{18} \mathrm{O}_{\text {ice }}$ in NGRIP on the GICC05 chronology (NGRIP, 2004). (b) Proxy reconstruction of Atlantic meridional overturning circulation (AMOC) from ${ }^{231} \mathrm{~Pa} /{ }^{230} \mathrm{Th}$ excess at the deep Bermuda Rise sites OCE326-GGC5/ODP1063 (black, McManus et al., 2004; grey, Bőhm et al., 2015). (c) Neodymium isotope records from Drake Passage LCDW corals, deep Cape Basin core RC11-83/TNO57-21 (foraminifera and sediment leachates; Piotrowski et al., 2008; Piotrowski et al., 2012), central Indian Ocean core SK129-CR2 (sediment leachates validated by foraminifera and fish teeth; Wilson et al., 2015), and Mid-Atlantic Ridge core MD07-3076 (foraminifera and fish teeth; Skinner et al., 2013). Uncertainties for coral $\mathrm{Nd}$ isotope data are $2 \sigma$, while uncertainties for coral ages are smaller than the symbol size. For clarity, uncertainties on the sediment core records are not shown. Horizontal bars highlight intervals when the Drake Passage corals match records from the Cape Basin (green bar), the central Indian Ocean (red bar), and the Mid-Atlantic Ridge (orange bar). (d) Antarctic temperature proxy $\delta^{18} \mathrm{O}_{\text {ice }}$ in WAIS Divide Core (WDC; WAIS Divide Project Members, 2015). YD, Younger Dryas; BA, Bølling-Allerød; HS1, Heinrich Stadial 1; LGM, Last Glacial Maximum; MIS 3, Marine Isotope Stage 3; AC, Antarctic Cold Reversal. 


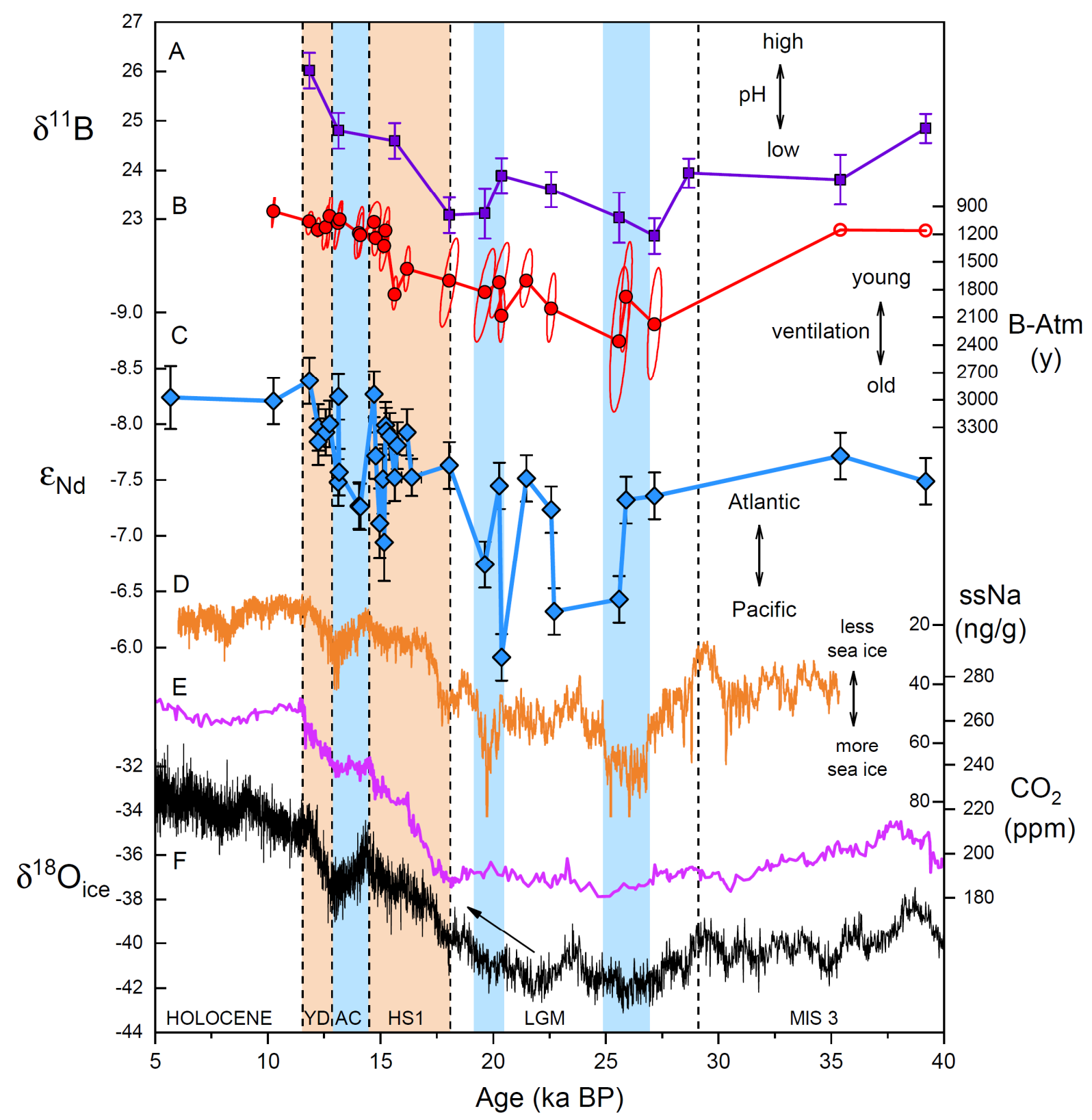

Fig. 4: Evolution of water mass sourcing and chemical properties of LCDW from 5 to $40 \mathrm{ka}$, based on Drake Passage deep-sea corals, compared to Southern Ocean climate records. (a) Deep water pH inferred from boron isotopes (Rae et al., 2018). (b) Deep water radiocarbon age offset from the contemporaneous atmosphere (B-Atm) (Burke and Robinson, 2012; Chen et al., 2015). Open symbols indicate two samples with large uncertainties in B-Atm and for clarity their error ellipses $( \pm \sim 2-2.5 \mathrm{kyr})$ are not shown. (c) Neodymium isotopes in LCDW corals (uncertainties for Nd isotopes are $2 \sigma$; uncertainties for ages are smaller than the symbol size). (d) Sea-salt sodium (ssNa, 15-point smoothed) in WAIS Divide Core as a proxy for sea-ice extent (WAIS Divide Project Members, 2015). (e) Atmospheric $\mathrm{CO}_{2}$ compilation from Antarctic ice cores (Bereiter et al., 2015). (f) Antarctic temperature proxy $\delta^{18} \mathrm{O}_{\text {ice }}$ in WAIS Divide Core (WAIS Divide Project Members, 2015), with arrow indicating early deglacial warming. Blue bars highlight the Antarctic Cold Reversal and two intervals during the LGM with particularly expanded sea-ice, which each correspond to shifts towards more radiogenic Nd isotopes. Orange bars highlight Antarctic warm intervals during the deglaciation. YD, Younger Dryas; AC, Antarctic Cold Reversal; HS1, Heinrich Stadial 1; LGM, Last Glacial Maximum; MIS 3, Marine Isotope Stage 3. 

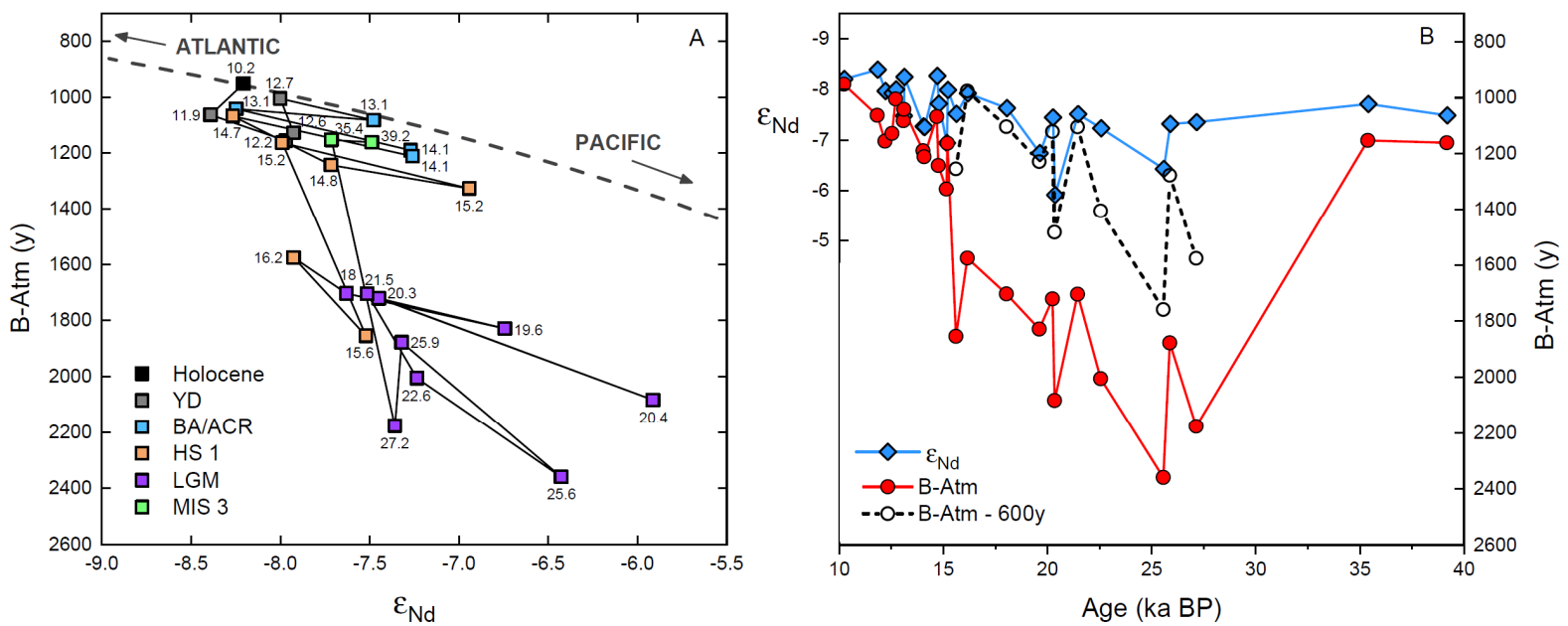

Fig. 5: Comparison of Nd isotopes and radiocarbon measured on the same LCDW coral specimens. (a) Cross-plot of $\mathrm{Nd}$ isotopes versus radiocarbon offset from the contemporaneous atmosphere (B-Atm). Data points are coloured by time interval and labelled with ages $(\mathrm{ka})$, while consecutive data points are connected by lines as a guide to temporal trends (but note that the inferred age sequence may occasionally be incorrect where adjacent samples have overlapping age uncertainties). Modern mixing line between Atlantic (NADW) and Pacific (Pacific Deep Water) water masses is also shown for comparison, based on modern endmember $\mathrm{Nd}$ isotopic compositions and concentrations (dashed grey line; see Struve et al. 2020 for details). (b) Time series of Nd isotopes (blue diamonds) and radiocarbon offset from the contemporaneous atmosphere (B-Atm, red circles). Scaling of the two y-axes approximately follows the modern mixing line shown in (a). Also shown is a portion of the radiocarbon data from 15.6 to $27.2 \mathrm{ka}$ with 600 years subtracted (black open circles and dashed line) to enable visual comparison with the Nd isotope record. For clarity, error bars are not shown on these plots (see Fig. 4). 


\section{References}

Adkins, J.F., Henderson, G.M., Wang, S.L., O'Shea, S., Mokadem, F., 2004. Growth rates of the deep-sea scleractinia Desmophyllum cristagalli and Enallopsammia rostrata. Earth Planet. Sci. Lett. 227, 481-490.

Allen, C.S., Pike, J., Pudsey, C.J., Leventer, A., 2005. Submillennial variations in ocean conditions during deglaciation based on diatom assemblages from the southwest Atlantic. Paleoceanography 20, PA2012, doi:2010.1029/2004PA001055.

Anderson, R.F., Ali, S., Bradtmiller, L.I., Nielsen, S.H.H., Fleisher, M.Q., Anderson, B.E., Burckle, L.H., 2009. Wind-driven upwelling in the Southern Ocean and the deglacial rise in atmospheric $\mathrm{CO}_{2}$. Science 323, 1443-1448.

Barker, S., Knorr, G., Vautravers, M.J., Diz, P., Skinner, L.C., 2010. Extreme deepening of the Atlantic overturning circulation during deglaciation. Nat. Geosci. 3, 567-571.

Basak, C., Fröllje, H., Lamy, F., Gersonde, R., Benz, V., Anderson, R.F., Molina-Kescher, M., Pahnke, K., 2018. Breakup of last glacial deep stratification in the South Pacific. Science 359, 900904.

Bereiter, B., Eggleston, S., Schmitt, J., Nehrbass-Ahles, C., Stocker, T.F., Fischer, H., Kipfstuhl, S., Chappellaz, J., 2015. Revision of the EPICA Dome C CO2 record from 800 to $600 \mathrm{kyr}$ before present. Geophys. Res. Lett. 42, 542-549.

Bőhm, E., Lippold, J., Gutjahr, M., Frank, M., Blaser, P., Antz, B., Fohlmeister, J., Frank, N., Andersen, M.B., Deininger, M., 2015. Strong and deep Atlantic meridional overturning circulation during the last glacial cycle. Nature 517, 73-76.

Bradtmiller, L.I., McManus, J.F., Robinson, L.F., 2014. ${ }^{231} \mathrm{~Pa} /{ }^{230} \mathrm{Th}$ evidence for a weakened but persistent Atlantic meridional overturning circulation during Heinrich Stadial 1. Nature Communications 5, 5817, doi: 5810.1038/ncomms6817.

Burke, A., Robinson, L.F., 2012. The Southern Ocean's role in carbon exchange during the last deglaciation. Science 335, 557-561.

Carter, P., Vance, D., Hillenbrand, C.D., Smith, J.A., Shoosmith, D.R., 2012. The neodymium isotopic composition of waters masses in the eastern Pacific sector of the Southern Ocean. Geochim. Cosmochim. Acta 79, 41-59.

Chen, T.Y., Robinson, L.F., Burke, A., Southon, J., Spooner, P., Morris, P.J., Ng, H.C., 2015. Synchronous centennial abrupt events in the ocean and atmosphere during the last deglaciation. Science 349, 1537-1541.

Cheon, W.G., Gordon, A.L., 2019. Open-ocean polynyas and deep convection in the Southern Ocean. Sci Rep 9, 6935, doi: 10.1038/s41598-019-43466-2

Clementi, V.J., Sikes, E.L., 2019. Southwest Pacific vertical structure influences on oceanic carbon storage since the Last Glacial Maximum. Paleoceanography and Paleoclimatology 34, 734-754.

Crosta, X., Sturm, A., Armand, L., Pichon, J.-J., 2004. Late Quaternary sea ice history in the Indian sector of the Southern Ocean as recorded by diatom assemblages. Mar. Micropaleontol. 50, 209-223.

Du, J., Haley, B.A., Mix, A.C., Walczak, M.H., Praetorius, S.K., 2018. Flushing of the deep Pacific Ocean and the deglacial rise of atmospheric CO2 concentrations. Nat. Geosci. 11, 749-755. 
Du, J.H., Haley, B.A., Mix, A.C., 2016. Neodymium isotopes in authigenic phases, bottom waters and detrital sediments in the Gulf of Alaska and their implications for paleo-circulation reconstruction.

671 Geochim. Cosmochim. Acta 193, 14-35.

Ferrari, R., Jansen, M.F., Adkins, J.F., Burke, A., Stewart, A.L., Thompson, A.F., 2014. Antarctic sea ice control on ocean circulation in present and glacial climates. Proc. Natl. Acad. Sci. U.S.A. 111, 8753-8758.

Garcia, H.E., Locarnini, R.A., Boyer, T.P., Antonov, J.I., Baranova, O.K., Zweng, W.M., Reagan, Utilization, and Oxygen Saturation, in: Levitus, S. (Ed.), NOAA Atlas NESDIS 75.

Gersonde, R., Crosta, X., Abelmann, A., Armand, L., 2005. Sea-surface temperature and sea ice distribution of the Southern Ocean at the EPILOG Last Glacial Maximum-a circum-Antarctic view based on siliceous microfossil records. Quat. Sci. Rev. 24, 869-896.

Hain, M.P., Sigman, D.M., Haug, G.H., 2010. Carbon dioxide effects of Antarctic stratification, North Atlantic Intermediate Water formation, and subantarctic nutrient drawdown during the last ice age: Diagnosis and synthesis in a geochemical box model. Glob. Biogeochem. Cycle 24, doi: $10.1029 / 2010 \mathrm{gb} 003790$.

Hillenbrand, C.-D., Bentley, M.J., Stolldorf, T.D., Hein, A.S., Kuhn, G., Graham, A.G.C., Fogwill, C.J., Kristoffersen, Y., Smith, J.A., Anderson, J.B., Larter, R.D., Melles, M., Hodgson, D.A., Antarctic Ice Sheet since the Last Glacial Maximum. Quat. Sci. Rev. 100, 111-136. doi: $11710.11038 /$ ncomms11765.

Hu, R., Piotrowski, A.M., 2018. Neodymium isotope evidence for glacial-interglacial variability of deepwater transit time in the Pacific Ocean. Nature Communications 9, 4709, doi: 4710.1038/s4146741018-07079-z.

Hu, R., Piotrowski, A.M., Bostock, H.C., Crowhurst, S., Rennie, V., 2016. Variability of neodymium isotopes associated with planktonic foraminifera in the Pacific Ocean during the Holocene and Last Glacial Maximum. Earth Planet. Sci. Lett. 447, 130-138.

Huang, H., Gutjahr, M., Eisenhauer, A., Kuhn, G., 2020. No detectable Weddell Sea Antarctic Bottom Water export during the Last and Penultimate Glacial Maximum. Nature Communications 11, 424, doi: 10.1038/s41467-41020-14302-41463. Physical Oceanography 27, 237-263.

Keeling, R.F., Stephens, B.B., 2001. Antarctic sea ice and the control of Pleistocene climate instability. Paleoceanography 16, 112-131. 
Lacan, F., Jeandel, C., 2005. Neodymium isotopes as a new tool for quantifying exchange fluxes at the continent-ocean interface. Earth Planet. Sci. Lett. 232, 245-257.

Lund, D.C., Adkins, J.F., Ferrari, R., 2011. Abyssal Atlantic circulation during the Last Glacial Maximum: Constraining the ratio between transport and vertical mixing. Paleoceanography 26, doi: 10.1029/2010pa001938.

Lynch-Stieglitz, J., Ito, T., Michel, E., 2016. Antarctic density stratification and the strength of the circumpolar current during the Last Glacial Maximum. Paleoceanography 31, 539-552.

Martínez-Botí, M.A., Marino, G., Foster, G.L., Ziveri, P., Henehan, M.J., Rae, J.W.B., Mortyn, P.G., Vance, D., 2015. Boron isotope evidence for oceanic carbon dioxide leakage during the last deglaciation. Nature 518, 219-222.

McCave, I.N., Crowhurst, S.J., Kuhn, G., Hillenbrand, C.D., Meredith, M.P., 2013. Minimal change in Antarctic Circumpolar Current flow speed between the last glacial and Holocene. Nat. Geosci. 7, 113-116.

McManus, J.F., Francois, R., Gherardi, J.M., Keigwin, L.D., Brown-Leger, S., 2004. Collapse and rapid resumption of Atlantic meridional circulation linked to deglacial climate changes. Nature 428, 834-837.

Muglia, J., Skinner, L.C., Schmittner, A., 2018. Weak overturning circulation and high Southern Ocean nutrient utilization maximized glacial ocean carbon. Earth Planet. Sci. Lett. 496, 47-56.

Nadeau, L.-P., Ferrari, R., Jansen, M.F., 2019. Antarctic sea ice control on the depth of North Atlantic Deep Water. J. Clim. 32, 2537-2551.

NGRIP, 2004. High-resolution record of Northern Hemisphere climate extending into the last interglacial period. Nature 431, 147-151.

Orsi, A.H., Whitworth, T., Nowlin, W.D., 1995. On the meridional extent and fronts of the Antarctic Circumpolar Current. Deep Sea Research Part I: Oceanographic Research Papers 42, 641-673.

Piotrowski, A.M., Galy, A., Nicholl, J.A.L., Roberts, N., Wilson, D.J., Clegg, J.A., Yu, J., 2012. Reconstructing deglacial North and South Atlantic deep water sourcing using foraminiferal Nd isotopes. Earth Planet. Sci. Lett. 357, 289-297.

Piotrowski, A.M., Goldstein, S.L., Hemming, S.R., Fairbanks, R.G., Zylberberg, D.R., 2008. Oscillating glacial northern and southern deep water formation from combined neodymium and carbon isotopes. Earth Planet. Sci. Lett. 272, 394-405.

Rae, J.W.B., Burke, A., Robinson, L.F., Adkins, J.F., Chen, T., Cole, C., Greenop, R., Li, T., Littley, E.F.M., Nita, D.C., Stewart, J.A., Taylor, B.J., 2018. $\mathrm{CO}_{2}$ storage and release in the deep Southern Ocean on millennial to centennial timescales. Nature 562, 569-573.

Rintoul, S.R., Hughes, C.W., Olbers, D., 2001. The Antarctic Circumpolar Current system, in: Siedler, G., Church, J., Gould, J. (Eds.), Ocean Circulation and Climate. Academic Press, pp. 271302.

Roberts, J., Gottschalk, J., Skinner, L.C., Peck, V.L., Kender, S., Elderfield, H., Waelbroeck, C., Vázquez Riveiros, N., Hodell, D.A., 2016. Evolution of South Atlantic density and chemical stratification across the last deglaciation. Proc. Natl. Acad. Sci. U.S.A. 113, 514-519. 
Robinson, L.F., Adkins, J.F., Frank, N., Gagnon, A.C., Prouty, N.G., Roark, E.B., van de Flierdt, T., 2014. The geochemistry of deep-sea coral skeletons: A review of vital effects and applications for palaeoceanography. Deep Sea Research Part II: Topical Studies in Oceanography 99, 184-198.

Robinson, L.F., van de Flierdt, T., 2009. Southern Ocean evidence for reduced export of North Atlantic Deep Water during Heinrich event 1. Geology 37, 195-198.

Shemesh, A., Hodell, D., Crosta, X., Kanfoush, S., Charles, C., Guilderson, T., 2002. Sequence of events during the last deglaciation in Southern Ocean sediments and Antarctic ice cores. Paleoceanography 17, 1056, doi: 1010.1029/2000PA000599.

Sigman, D.M., Hain, M.P., Haug, G.H., 2010. The polar ocean and glacial cycles in atmospheric $\mathrm{CO}_{2}$ concentration. Nature 466, 47-55.

Sikes, E.L., Allen, K.A., Lund, D.C., 2017. Enhanced $\delta^{13} \mathrm{C}$ and $\delta^{18} \mathrm{O}$ differences between the South Atlantic and South Pacific during the last glaciation: The deep gateway hypothesis. Paleoceanography 32, 1000-1017.

Skinner, L.C., 2009. Glacial-interglacial atmospheric $\mathrm{CO}_{2}$ change: a possible "standing volume" effect on deep-ocean carbon sequestration. Clim. Past. 5, 537-550.

Skinner, L.C., Fallon, S., Waelbroeck, C., Michel, E., Barker, S., 2010. Ventilation of the deep Southern Ocean and deglacial $\mathrm{CO}_{2}$ rise. Science 328, 1147-1151.

Skinner, L.C., Primeau, F., Freeman, E., de la Fuente, M., Goodwin, P.A., Gottschalk, J., Huang, E., McCave, I.N., Noble, T.L., Scrivner, A.E., 2017. Radiocarbon constraints on the glacial ocean circulation and its impact on atmospheric CO2. Nature Communications 8, 16010, doi: 16010.11038/ncomms16010.

Skinner, L.C., Scrivner, A.E., Vance, D., Barker, S., Fallon, S., Waelbroeck, C., 2013. North Atlantic versus Southern Ocean contributions to a deglacial surge in deep ocean ventilation. Geology 41, 667670 .

Smith, J.A., Hillenbrand, C.-D., Pudsey, C.J., Allen, C.S., Graham, A.G.C., 2010. The presence of polynyas in the Weddell Sea during the Last Glacial Period with implications for the reconstruction of sea-ice limits and ice sheet history. Earth Planet. Sci. Lett. 296, 287-298.

Stein, K., Timmermann, A., Kwon, E.Y., Friedrich, T., 2020. Timing and magnitude of Southern Ocean sea ice/carbon cycle feedbacks. Proc. Natl. Acad. Sci. U.S.A. 117, 4498-4504.

Struve, T., van de Flierdt, T., Burke, A., Robinson, L.F., Hammond, S.J., Crocket, K.C., Bradtmiller, L.I., Auro, M.E., Mohamed, K.J., White, N.J., 2017. Neodymium isotopes and concentrations in aragonitic scleractinian cold-water coral skeletons - Modern calibration and evaluation of palaeoapplications. Chemical Geology 453, 146-168.

Struve, T., van de Flierdt, T., Robinson, L.F., Bradtmiller, L.I., Hines, S.K., Adkins, J.F., Lambelet, M., Crocket, K.C., Kreissig, K., Coles, B., Auro, M.E., 2016. Neodymium isotope analyses after combined extraction of actinide and lanthanide elements from seawater and deep-sea coral aragonite. Geochemistry, Geophysics, Geosystems 17, 232-240.

Struve, T., Wilson, D.J., van de Flierdt, T., Pratt, N., Crocket, K.C., 2020. Middle Holocene expansion of Pacific Deep Water into the Southern Ocean. Proc. Natl. Acad. Sci. U.S.A. 117, 889894. 
Sudre, J., Garçon, V., Provost, C., Sennéchael, N., Huhn, O., Lacombe, M., 2011. Short-term variations of deep water masses in Drake Passage revealed by a multiparametric analysis of the ANTXXIII/3 bottle data. Deep Sea Research Part II: Topical Studies in Oceanography 58, 2592-2612.

Talley, L.D., 2013. Closure of the global overturning circulation through the Indian, Pacific, and Southern Oceans: Schematics and Transports. Oceanography 26, 80-97.

Toggweiler, J.R., 1999. Variation of atmospheric $\mathrm{CO}_{2}$ by ventilation of the ocean's deepest water. Paleoceanography 14, 571-588.

van de Flierdt, T., Griffiths, A.M., Lambelet, M., Little, S.H., Stichel, T., Wilson, D.J., 2016. Neodymium in the oceans: a global database, a regional comparison and implications for palaeoceanographic research. Philosophical Transactions of the Royal Society A: Mathematical, Physical and Engineering Sciences 374, doi: 10.1098/rsta.2015.0293.

van de Flierdt, T., Robinson, L.F., Adkins, J.F., 2010. Deep-sea coral aragonite as a recorder for the neodymium isotopic composition of seawater. Geochim. Cosmochim. Acta 74, 6014-6032.

WAIS Divide Project Members, 2013. Onset of deglacial warming in West Antarctica driven by local orbital forcing. Nature 500, 440-444.

WAIS Divide Project Members, 2015. Precise interpolar phasing of abrupt climate change during the last ice age. Nature 520, 661-665.

Watson, A.J., Ledwell, J.R., Messias, M.-J., King, B.A., Mackay, N., Meredith, M.P., Mills, B., Naveira Garabato, A.C., 2013. Rapid cross-density ocean mixing at mid-depths in the Drake Passage measured by tracer release. Nature 501, 408-411.

Weber, M.E., Clark, P.U., Ricken, W., Mitrovica, J.X., Hostetler, S.W., Kuhn, G., 2011. Interhemispheric Ice-Sheet Synchronicity During the Last Glacial Maximum. Science 334, 1265 1269.

Wilson, D.J., Piotrowski, A.M., Galy, A., Banakar, V.K., 2015. Interhemispheric controls on deep ocean circulation and carbon chemistry during the last two glacial cycles. Paleoceanography 30, 621641.

Xiao, W., Esper, O., Gersonde, R., 2016. Last Glacial-Holocene climate variability in the Atlantic sector of the Southern Ocean. Quat. Sci. Rev. 135, 115-137.

Yu, J., Menviel, L., Jin, Z.D., Thornalley, D.J.R., Barker, S., Marino, G., Rohling, E.J., Cai, Y., Zhang, F., Wang, X., Dai, Y., Chen, P., Broecker, W.S., 2016. Sequestration of carbon in the deep Atlantic during the last glaciation. Nat. Geosci. 9, 319-324.

Zhao, N., Oppo, D.W., Huang, K.-F., Howe, J.N., Blusztajn, J., Keigwin, L.D., 2019. Glacialinterglacial Nd isotope variability of North Atlantic Deep Water modulated by North American ice sheet. Nature Communications 10, 5773, doi: 5710.1038/s41467-41019-13707-z. 